Pesq. Vet. Bras. 29(2):120-124, fevereiro 2009

\title{
An enzyme-linked immunosorbent assay (ELISA) for the detection of IgM antibodies against Leishmania chagasi in dogs ${ }^{1}$
}

\author{
Débora Carvalho², Trícia M.F.S. Oliveira², Cristiane D. Baldani² and \\ Rosangela Z. Machado ${ }^{*}$
}

\begin{abstract}
Carvalho D., Oliveira T.M.F.S., Baldani C.D. \& Machado R.Z. 2009. An enzyme-linked immunosorbent assay (ELISA) for the detection of IgM antibodies against Leishmania chagasi in dogs. Pesquisa Veterinária Brasileira 29(2):120-124. Departamento de Patologia Veterinária, Universidade Estadual Paulista, Faculdade de Ciências Agrárias e Veterinárias, Via de Acesso Prof. Paulo Donato Castellane s/n, Jaboticabal, SP 14870-000, Brazil. E-mail: zacarias@fcav.unesp.br

Visceral leishmaniasis is an emergent zoonosis with an increasing number of new cases in Brazil where the domestic dog is an important parasite reservoir in the infectious cycle of Leishmania chagasi. An enzyme-linked immunosorbent assay (ELISA), based upon the use of a total soluble antigenic preparation of $L$. chagasi, was adapted for the detection of IgM antibodies in the serum of infected dogs. Optimal dilutions of the antigen, using positive and negative reference sera, were determined by checkboard titrations. The specificity and sensitivity of the ELISA were $100 \%$. A total of 110 serum samples were taken from dogs in Belo Horizonte, Minas Gerais, Brazil, and examined for anti-L. chagasi lgM antibody by ELISA and indirect fluorescent antibody test (IFAT). About $25 \%(n=27)$ of all the dogs tested were found serologically positive for $L$. chagasi by IFAT, while $89.09 \%(n=98)$ were seropositive by ELISA. The results obtained by ELISA and IFAT were significantly different $(P<0.01)$. The combined use of ELISA and IFAT is recommended in order to enable veterinary services to more efficiently detect canine visceral leishmaniasis.
\end{abstract}

INDEX TERMS: Leishmania chagasi, diagnosis, dogs, IgM, enzyme-linked immunosorbent assay.

RESUMO.- [Ensaio imunoenziático (ELISA) para detecção de anticorpos IgM contra Leishmania chagasi em cães.] A leishmaniose visceral é uma zoonose emergente, com elevado número de novos casos no Brasil, onde o cão doméstico é um importante reservatório do parasito no ciclo infeccioso da Leishmania chagasi. Um ensaio de imunoadsorção enzimática (ELISA) baseado em antígeno bruto de $L$. chagasi foi adaptado para a detecção de anticorpos IgM em soros de cães infectados. As diluições ótimas do antígeno e dos soros controles positivo e negativo foram determinadas através de titulação em bloco. A sensibilidade e especificidade do ELISA teste foram de $100 \%$.

\footnotetext{
${ }^{1}$ Received on February 12, 2008.

Accepted for publication on October 8, 2008.

${ }^{2}$ Departamento de Patologia Veterinária, Faculdade de Ciências Agrárias e Veterinárias (FCAV), Universidade Estadual Paulista (Unesp), Via de Acesso Prof. Paulo Donato Castellane s/n, Jaboticabal, SP 14870000, Brazil. *Author for correspondence: zacarias@fcav.unesp.br
}

Um total de 110 amostras de soros foram obtidas de cães oriundos de Belo Horizonte, Minas Gerais, Brasil, e avaliadas pelo ELISA e pela reação de imunofluorescência indireta (RIFI) para anticorpos IgM anti-L. chagasi. Aproximadamente $25 \%(n=27)$ dos cães testados foram sorologicamente positivos para L. chagasi pela RIFI, enquanto $89.09 \%$ foram soropositivos pelo ELISA. Os resultados obtidos pelo ELISA e pela RIFI foram significativamente diferentes $(P<0.01)$. A associação do ELISA e da RIFI deve ser recomendada a fim de permitir a detecção mais eficiente da leishmaniose visceral canina pelos serviços veterinários.

TERMOS DE INDEXAÇÃO: Leishmania chagasi, diagnóstico, cães, IgM, ensaio imunoenzimático.

\section{INTRODUCTION}

American visceral leishmaniasis (AVL) is a chronic wasting disease characterized by the infection of mononuclear phagocytes by Leishmania (Leishmania) chagasi. The 
parasite life cycle includes the sand fly Lutzomyia longipalpis and the domestic dog as an important peridomestic reservoir. Leishmaniasis is widespread in tropical and subtropical areas of Latin America, Europe, Africa and Asia and is increasingly becoming a major public health problem (WHO 1999). An increased prevalence of human and canine AVL has been reported in Brazil, not only in terms of the number of cases and but also in terms of the geographical dispersion of the disease (Feitosa et al. 2000, Nunes et al. 2001, Silva et al. 2001, Cabrera et al. 2003, França-Silva et al. 2003). The disease is more prevalent among dogs than human beings and it has been shown that canine cases usually precede human cases. In fact, canine visceral leishmaniasis (CVL) has been considered a risk factor for human visceral leishmaniasis (HVL) (Di Lorenzo et al. 2000).

Clinical manifestations of CVL are many and include weight loss, elongated and deformed nails, mouth ulcers, skin lesions, hair loss, keratoconjuctivitis, dermatitis and lymphadenopathy. However, dogs infected with L. chagasi may present the disease in a severe form, remain asymptomatic, resist the clinical disease for long periods, or develop a few symptoms that may disappear spontaneously (Cordeiro-da-Silva et al. 2003). The severity of the infection depends on the parasite strain, host genetic background and host health and nutritional status. In this sense, a rapid and reliable diagnostic method would be a vital tool for the clinician, especially because clinical signs are only observed in a low proportion of infected dogs (Gradoni 1995).

Diagnosis of CVL can be made by means of parasitological, serological or molecular methods, associated with clinical and epidemiological evidence. Direct microscopic examination and in vitro culture of bone marrow aspirates, spleen and lymph node biopsy specimens are elected as methods for diagnosis and have been considered "gold standards". However, these methods are invasive, painful and even hazardous. Additionally, parasite detection in biopsy samples is influenced by several factors, including organ distribution and culturing which may be unsuccessful due to contamination (Ozbel et al. 2000).

Several serological tests have been developed and evaluated for the diagnosis of VL including indirect fluorescent antibody test (IFAT); enzyme-linked immunosorbent assay (ELISA); Dot-ELISA; immunoblot analysis; and direct agglutination test (DAT) (Islam et al. 2002). The presence of antiparasite antibodies is routinely used as a marker of infection with the production of antibody as the definition of infection or challenge. Generally serological methods present high sensitivity and specificity, although cross reactions with other infectious agents have been reported and the choice of a suitable cutoff value may not be obvious (Dye et al. 1993). Additionally, these tests may be restricted by antibody detection limits and false-positive and false-negative results (Slappendel \& Greene 1990, Ferrer et al. 1995,
Santa Rosa \& Oliveira 1997), resulting in the unnecessary euthanasia of dogs or maintenance of a reservoir in endemic areas. Overall, the reported performance of these tests indicates that in general they are suitable tools for the serodiagnosis of CVL in both symptomatic and asymptomatic dogs.

Molecular biological techniques such as polymerase chain reaction (PCR) alone or in combination with hybridization have been used for detecting VL in humans and dogs (Berrahal et al. 1996, Martin-Sanchez et al. 2001). Despite the high sensitivity and specificity, ability to detect and identify the protozoa involved and the ability to be applied directly on clinical samples, these techniques remain quite complex and laborious, therefore most applicable for research use (Ikonomopoulos et al. 2003).

The program established in Brazil to control VL is based on the guidelines recommended by the World Health Organization (WHO 1999). Among the recommended strategies, detection and treatment of human cases; control of the vector population; and control of domestic reservoirs are most often employed. This control method is based on the interruption of the transmission cycle, using direct measures involving the main vector Lutzomyia longipalpis and the domestic dog (Madeira et al. 2004). Hence, efforts should be made to develop an assay capable of detecting infection as early as possible in asymptomatic carriers.

The aim of our investigation was to develop an enzymelinked immunosorbent assay (ELISA) using total soluble antigen of $L$. chagasi for the detection of IgM antibodies anti-L. chagasi in dogs and compare its performance to the indirect fluorescent antibody test (IFAT). We also investigated the occurrence of IgM antibody titres in dog sera from the endemic area of Belo Horizonte, the state of Minas Gerais, Brazil.

\section{MATERIALS AND METHODS}

\section{Source of Leishmania chagasi promastigotes}

A Leishmania sp. strain isolated in Araçatuba, São Paulo, Brazil, characterized as complex Donovani, probably L. chagasi, using molecular techniques described by Cortes et al. (2004), was used in this study. The parasites were maintained in an RPMI- 1640 medium at $25^{\circ} \mathrm{C}$ and were used to prepare antigens for IFAT and ELISA.

\section{Serum samples}

The positive Leishmania sp. reference group consisting of 110 serum samples was kindly supplied by the Centro de Pesquisas René Rachou/ Fiocruz, Belo Horizonte, the state of Minas Gerais, Brazil, which is an endemic area for the occurrence of CVL (Barbosa-de-Deus et al. 2002). A sera panel of known origin, including 15 serum samples obtained from puppies in the city of Jaboticabal, the state of São Paulo, Brazil, was considered a negative reference group, since the area is not endemic for leishmaniasis.

\section{Indirect fluorescent antibody test (IFAT)}

The IFAT was carried out according to Oliveira et al. (2008) for IgG antibodies in order to screen positive IgM control serum samples for the ELISA test. Promastigotes of L. chagasi, for 
antigen preparation, were washed three times in PBS with $1 \%$ BSA and resuspended in PBS-buffered formalin for 30 minutes. The parasites were washed three times again in PBS 1\% BSA, and the pellet was resuspended in PBS so that $10 \mathrm{ml}$ yielded 20 to 25 parasites per microscope field $(400 x)$. Slides with twelve previously marked circles were supplied with $10 \mathrm{ml}$ for each circle and then frozen at $-20^{\circ} \mathrm{C}$ until use. Slides with promastigote forms of the parasite were stabilized at room temperature for the IFAT procedure. Doubling serum dilutions were used, starting at 1:40. The samples were placed over the antigen in the slides and incubated in a moist chamber at $37^{\circ} \mathrm{C}$ for 30 minutes. The slides were washed three times in PBS, and incubated with antidog IgM serum conjugated for fluorescein isothiocyanate (KPL, USA) diluted at 1:30 in PBS containing 1mg\% Evan's Blue. The slides were washed again in PBS, covered with buffered glycerin and a cover slip, and then examined on a fluorescent microscope. In all the experiments, reference sera were included as negative and positive controls. For positive serum samples, parasites displayed a bright-green peripheral stain with a dull fluorescence of the cytoplasm and were considered positive serum samples at 1:40 or more.

\section{Enzyme-linked immunosorbent assay (ELISA)}

The ELISA was originally described by Oliveira et al. (2008). To summarize, $100 \mathrm{~mL}$ of $L$. chagasi total soluble antigen diluted in a sodium bicarbonate-carbonated $0.05 \mathrm{M}$ buffer $(\mathrm{pH} 9.6)$ was added per well to an ELISA plate (Nunclon ${ }^{\mathrm{TM}}$ surface; Nunc, Denmark) and protein concentration was adjusted to $5 \mu \mathrm{g} / \mathrm{mL}$, $10 \mu \mathrm{g} / \mathrm{mL}, 20 \mu \mathrm{g} / \mathrm{mL}$ and $40 \mu \mathrm{g} / \mathrm{mL}$. After overnight incubation at $4^{\circ} \mathrm{C}$, plates were washed three times with PBS Tween-20 at $0.05 \%$. The plates were blocked with $200 \mathrm{~mL}$ containing $6 \%$ skim milk for 2 hours at $37^{\circ} \mathrm{C}$, to reduce non-specific binding. The blocking agent was removed, and individual dog serum diluted (1:100) in PBS Tween-20 with 5\% skim milk added to each well and then incubated for 90 minutes at $37^{\circ} \mathrm{C}$, and washed as described above. One hundred $\mathrm{mL}$ of alkaline phosphatase conjugated anti-dog IgM (Sigma Chemical Co) diluted at 1:50 in PBS Tween-20 with 5\% normal rabbit serum was added to each well and then incubated for 90 minutes at $37^{\circ} \mathrm{C}$. The plates were washed and the substrate ( $p$-nitrophenyl phosphate) diluted in dietanolamine buffer, $\mathrm{pH}$ 9.8, was added. Absorbance at 405nm was read after 45 minutes incubation at room temperature using an ELISA reader (Dynex Technologies, USA). Optimal dilutions of antigen and positive and negative sera were determined by checkboard titrations (Machado et al. 1997). The immunological reactivity of each serum was calculated using the following equation: (mean sample absorbance - mean absorbance of negative serum reference)/(mean absorbance of positive reference serum - mean absorbance of negative serum reference). $S / P$ values were grouped into ELISA levels (EL), which ranged from 0 (lowest level) to 9 (highest level), as described by Machado et al. (1997). The discriminating absorbance value (cut-off) was determined as being two and a half times the mean absorbance value of the negative group, where readings above the cut-off value were considered positive. Specificity was defined as the proportion of known negative serum samples detected as negative and the sensitivity was defined as the proportion of known positive serum samples detected as positive.

\section{Statistical analysis}

The McNemar test for nonindependent samples was used to compare the ELISA results to those of the IFAT (Baldock 1988). A $P$ value of $<0.01$ was considered significant.

\section{RESULTS}

Checkboard titrations showed an antigen concentration of $10 \mathrm{mg} / \mathrm{mL}$ in carbonate buffer, $\mathrm{pH}$ 9.6, as optimum. Serum samples, including positive and negative reference sera, were diluted at 1:100. The average absorbance of negative sera was $0.115 \pm 0.02$, resulting in a calculated cut-off value of 0.288 (EL 3, Table 1). The mean absorbance value of the anti-Leishmania sp serum group $(1.418+0.243)$ was about 12 times greater than that obtained with non-infected sera, clearly discriminating between the mean absorbances of positive and negative reference sera. This data gave a sensitivity and specificity of $100 \%$. The EL was determined as shown in Table 1.

IFAT and ELISA results for sera samples obtained from Belo Horizonte, the state of Minas Gerais State are summarized in Table 2. Statistical analysis showed significant differences between the results $(P<0.01)$. IgM

\begin{tabular}{cc}
$\begin{array}{c}\text { Table 1. S/P values for ELISA } \\
\text { levels (EL) } \mathbf{0 - 9}\end{array}$ \\
\hline EL & Absorbance value \\
\hline 0 & $0-0.155$ \\
1 & $0.156-0.209$ \\
2 & $0.210-0.282$ \\
3 & $0.283-0.381$ \\
4 & $0.382-0.514$ \\
5 & $0.515-0.694$ \\
6 & $0.695-0.937$ \\
7 & $0.938-1.265$ \\
8 & $1.266-1.708$ \\
9 & $\geq 1.709$
\end{tabular}

Table 2. Summary ${ }^{\mathrm{a}}$ of ELISA and IFAT results for the sera samples obtained from dogs $(n=110)$ raised in endemic area of Belo Horizonte, the state of Minas Gerais, Brazil

\begin{tabular}{lcc}
\hline \multicolumn{1}{c}{ ELISA } & \multicolumn{2}{c}{ IFAT } \\
\cline { 2 - 3 } & $\begin{array}{c}\text { Leishmania chagasi } \\
\text { positive }\end{array}$ & $\begin{array}{c}\text { L. chagasi } \\
\text { negative }\end{array}$ \\
\hline $\begin{array}{l}\text { L. chagasi positive } \\
\text { L. chagasi negative }\end{array}$ & 27 & 71 \\
\hline
\end{tabular}

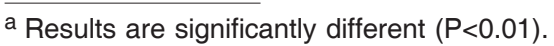

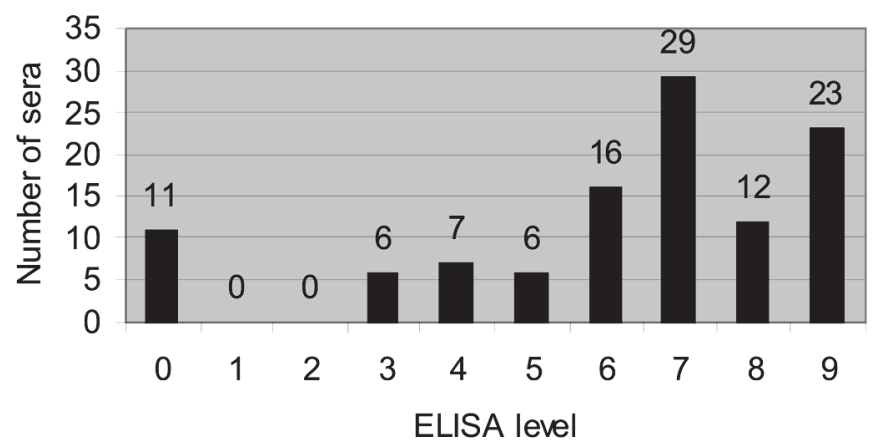

Fig.1. Number of sera from dogs $(n=110)$ raised in endemic area of Belo Horizonte, the state of Minas Gerais, Brazil, screened by IgM ELISA against Leishmania chagasi soluble antigen and plotted by ELISA level (EL). 
antibody against Leishmania sp. soluble antigen were detected in only $24.55 \%(n=27)$ of the dogs by IFAT, with titres ranging from $1: 80$ to $1: 320$. On the other hand, the estimated ELISA values demonstrated that $89.09 \%(n=98)$ of the dogs had EL $3-9$, with only $10.91 \%(n=12)$ of the serum samples being negative for IgM. The results of sera number distributed through EL are shown in Figure 1.

\section{DISCUSSION}

American visceral leishmaniasis in Brazil is considered to be a zoonotic disease which was formerly restricted to rural and sub-urban areas. Today, due to the emergence of new foci of the disease in urban areas, it has become increasingly important to public health.

The diagnosis of AVL in both human beings and dogs remains a difficult task. Current methods rely on clinical signs, parasite identification in aspirated material and serology. The direct observation of amastigote forms in smears is a safe method, but the sensitivity is reduced. Serological methods, on the other hand, are widely used in endemic areas as a determining factor for the elimination of dogs but usually lack sensitivity, and frequently underestimate the real incidence of the infection. Therefore there is an increasing need for more specific and sensitive diagnostic methods to be developed.

The ELISA described in this article is based on the use of reference sera to clearly define the difference between IgM negative and positive sera and to calibrate ELISA absorbance as a score over a wide range of antibody levels. Positive controls used on the standardization of the ELISA were obtained from Belo Horizonte, the state of Minas Gerais, an endemic area for VL in Brazil. Negative controls were obtained from dogs native to Jaboticabal, the state of São Paulo, a non-endemic area for the disease. These negative reference sera were collected during a rabies vaccination program and were immunologically tested for IgG antibodies anti-Leishmania sp. by IFAT and ELISA (Oliveira et al., 2008). The results have demonstrated that a soluble antigen of $L$. chagasi prepared from in vitro culture of the parasite could be used in a sensitive and specific ELISA to detect IgM antibodies for Leishmania $\mathrm{sp}$.

In our study, IFAT was considered the gold standard, and the results obtained from this test were considered "true". Statistical analysis showed significant differences between the ELISA and the IFAT results $(P<0.01)$, indicating a poor correlation between both tests (Table 2), although the sensitivity and specificity of the IgM ELISA were $100 \%$. An ELISA can detect antibodies binding to multiple antigenic determinants of the parasite as these are ruptured during antigen preparation and a wide range of antigen is exposed. On the other hand, IFAT detects anti-Leishmania sp. antibodies that are directed against surface proteins.

This study suggests that the ELISA described herein is more sensitive than IFAT for the detection of IgM antibodies anti-Leishmania sp. Similar results were also reported by Bouer (2001), who recorded a higher sensitivity in the ELISA compared to IFAT in the detection of antiToxoplasma gondii IgM antibodies in naturally infected monkeys (IFAT-96\%, ELISA-53\%). It should be mentioned, however, that when IgG anti-T. gondii antibodies were analyzed, the sensitivity of ELISA and IFAT were similar (IFAT- 65\%, ELISA-68\%). Additionally, Bouer (2005) observed that IgM anti- $T$. gondii antibodies in experimentally infected monkeys are detected up to the $15^{\mathrm{TH}}$ day of infection by IFAT and up to the $120^{\mathrm{TH}}$ day of infection by ELISA, while IgG antibodies were detected up to the end of the experiment. Also, Carvalho (1999) observed that ELISA-IgM is more sensitive than IFAT-IgM in experimentally infected cats.

IgM is an antibody associated with acute forms of several parasite diseases. However, IgM anti-L. chagasi are detected, respectively, after the first and fifth month of acute and chronic infection, maintaining high levels during the course of infection (Genaro 1993). High IgM titres are present in dogs, which are naturally infected with $L$. chagasi, and there is no difference between titres of asymptomatic, oligosymptomatic and symptomatic dogs (Reis 2001). Lucena \& Ginel (1998) analyzing sera from dogs which are naturally infected with $L$. chagasi by IFAT, found that $91.7 \%(n=11)$ of the dogs presented $\operatorname{lgM}, 41.7 \%(n=5)$ $\lg$ and $33.3 \%(n=4) \lg A$, the three imunoglobulin isotypes were not detected simultaneously.

Although IFAT is the serological method used by the Fundação Nacional de Saúde in the Brazilian program for the control of visceral leishmaniasis, several studies have demonstrated that IFAT has low sensitivity and may lead to false-negative results (Braga et al. 1998, Silva et al. 2001). Additionally, standardization is difficult considering the subjective judgement of the reader and it is a timeconsuming method, especially for seroepidemiological studies. Hence, ELISA should be considered an alternative to IFAT or even a complementary method, especially because it permits the simultaneous analysis of a large sample number in a short time, and where data readings are automatically performed and antigen concentration is both small and determined.

In conclusion, we have provided convincing data demonstrating the usefulness of ELISA using total soluble antigenic preparation in the detection of anti-L. chagasi $\operatorname{lgM}$ antibodies. The combined use of ELISA and IFAT is recommended in order to enable veterinary services to more efficiently detect CVL.

Acknowledgements.- This study was supported by grants from the Fundação de Amparo à Pesquisa do Estado de São Paulo (FAPESP, Proc.04/06696-8), Brazil.

\section{REFERENCES}

Baldock F.C. 1988. Epidemiological evaluations of immunological tests, p.90-95. In: Burgess G.W. (Ed.), ELISA technology in diagnosis and research. Graduate School of Tropical Veterinary Science, James Cook University of North Queensland, Townsville, Australia.

Barbosa-de-Deus R., Dos Mares-Guia M.L., Nunes A.Z., Costa K.M., 
Junqueira R.G., Mayrink W., Genaro O. \& Tavares C.A. 2002. Leishmania major-like antigen for specific and sensitive serodiagnosis of human and canine visceral leishmaniasis. Clin. Diagn. Lab. Immunol. 9(5):1361-1366.

Berrahal F., Mary C., Roze M., Beremger A., Escoffier K., Lamouroux D. \& Dunan S. 1996. Canine leishmaniasis: identification of asymptomatic carriers by polymerase chain reaction and immunoblotting. Am. J. Trop. Med. Hyg. 55:273-277.

Bouer A. 2001. Detecção de anticorpos anti-Toxoplasma gondii através das técnicas de imunofluorescência indireta e Elisa e diagnóstico diferencial com o Neospora caninum em primatas experimentalmente e naturalmente infectados. Dissertação de Mestrado em Patologia Animal, Faculdade de Ciências Agrárias e Veterinárias, Universidade Estadual Paulista, Jaboticabal. 91p.

Bouer A. 2005. Estudo da resposta imune humoral e celular em macacos-prego (Cebus apella) experimentalmente infectados com Toxoplasma gondii. Tese de Doutorado em Patologia Animal, Faculdade de Ciências Agrárias e Veterinárias, Universidade Estadual Paulista, Jaboticabal. 95p.

Braga M.D.M., Coêlho I.C.B., Pompeu M.M.L., Evans T.G., MacAullife I.T., Teixeira M.J. \& Lima J.W.O. 1998. Controle do calazar canino: comparação dos resultados de um programa de eliminação rápida de cães sororreagentes por ensaio imuno-enzimático com outro de eliminação tardia de cães sororreagentes por teste de imunofluorescência indireta de eluato de papel de filtro. Revta Soc. Bras. Med. Trop. 31(5):419-424.

Cabrera A.A.M., De Paula A.A., Camacho L.A.B., Marzochi C.A., Aguiar G.M. \& Xavier S.C. 2003. Canine visceral leishmaniasis in Barra de Guaratiba, Rio de Janeiro, Brazil: Assesment of risck factors. Revta Inst. Med. Trop. São Paulo 45(2):79-83.

Carvalho C.S. 1999. Padronização do Elisa-Teste para a detecção de anticorpos das classes IgM e IgG em soros de gatos experimentalmente infectados com taquizoítos de $T$. gondii. Dissertação de Mestrado em Patologia Animal, Faculdade de Ciências Agrárias e Veterinárias, Universidade Estadual Paulista, Jaboticabal. 76p.

Cordeiro-da-Silva A., Cardoso L., Araujo N., Castro H., Tomas A., Rodrigues M., Cabral M., Vergnes B., Sereno D. \& Ouaissi A. 2003. Identification of antibodies to Leishmania silent information regulatory 2 (SIR 2) protein homologue during canine natural infections: pathological implications. Immunol. Lett. 68(2):155-162.

Cortes S., Rolão N., Ramada J. \& Campino L. 2004. PCR as a rapid and sensitive tool in the diagnosis of human and canine leishmaniasis using Leishmania donovani s.l.- specific kinetoplastid primers. T. Roy. Soc. Trop. Med. H., 98(1):12-17.

Di Lorenzo C., Proietti F.A. \& Assunção R.M. 2000. A urbanização da leishmaniose visceral no Brasil: uma breve revisão. Revta Soc. Bras. Med. Trop. 33:316-317.

Dye C., Vidor E. \& Dereure J. 1993. Serological diagnosis of leishmaniasis: On detecting infection as well as diseases. Epidemiol. Infect. 103:647-656.

Feitosa M.M., Ikeda F.A., Luvizotto M.V.R. \& Perri S.H.V. 2000. Aspectos clínicos de cães com leishmaniose visceral no município de Araçatuba, São Paulo (Brasil). Clin. Vet. 5(28):36-44.

Ferrer L., Aisa M.J., Roura X. \& Portus M. 1995. Serological diagnosis and treatment of canine leishmaniasis. Vet. Rec. 136(20):514-516.

França-Silva J.C., da Costa R.T., Siqueira A.M., Machado-Coelho G.L., da Costa C.A., Mayrink W., Vieira E.P., Costa J.S., Genaro O. \& Nascimento E. 2003.Epidemiology of canine visceral leishmaniosis in the endemic area of Montes Claros Municipality, Minas Gerais State, Brazil. Vet. Parasitol. 111(2-3):161-173.

Genaro O. 1993. Leishmaniose visceral canina experimental. Tese de
Doutorado em Parasitologia, Universidade Federal de Minas Gerais, Belo Horizonte. 202p.

Gradoni L.M. 1995. Canine reservoir of zoonotic visceral lishmaniasis in the Mediterranean area: Epidemiology and control. Information Circular, WHO Mediterranean Zoonoses Control Centre, Greece.

Ikonomopoulus J., Kokotas S., Gazouli M., Zavras A., Stoitsiou M. \& Gorgoulis V.G. 2003. Molecular diagnosis of leishmaniosis in dogs: Comparative application of traditional diagnostic methods and the proposed assay on clinical samples. Vet. Parasitol. 113:99-113.

Islam M.Z., Itoh M., Shamsuzzaman S.M., Mirza R., Matin F., Ahmed I., Shamsuzzaman Choudhury A.K., Hossain M.A., Qiu X.G., Begam N., Furuya M., Leafasia J.L., Hashiguchi Y., Kimura E. 2002. Diagnosis of visceral leishmaniasis by Enzyme-Linked Immunosorbent Assay using urine samples. Clin. Diagn. Lab. Immunol. 9(4):789-794.

Lucena R. \& Ginel P.J. 1998. Immunoglobulin isotype distribution of antinuclear antibodies in dogs with leishmaniasis. Res. Vet. Sci. 65(3):205-207.

Machado R.Z., Moantassier H.J., Pinto A.A., Lemos E.G., Machado M.R.F., Valadão I.F.F., Barci L.G. \& Malheiros E.B. 1997. An enzymelinked immunosorbent assay (ELISA) for the detection of antibodies against Babesia bovis in cattle. Vet. Parasitol. 71(1):17-26.

Madeira M.F., Schubach A.O., Schubach T.M.P., Leal C.A. \& Marzochi M.C.A. 2004. Identification of Leishmania (Leishmania) chagasi isolated from healthy skin of symptomatic and asymptomatic dogs seropositive for leishmaniasis in the Municipality of Rio de Janeiro, Brazil. Braz. J. Infect. Dis. 8(6):440-444.

Martin-Sanchez J., Lopez-Lopez M.C., Acedo-Sanchez C., CastroFajardo J.J., Pineda J.A. \& Morillas-Marquez F. 2001. Diagnosis of infection with Leishmania infantum using PCR-ELISA. Parasitol. 122:607-615.

Nunes V.L., Galati E.A.B., Nunes D.B., Zinezzi R.O., Savani E.S.M.M., Ishikawa E., Camargo M.C.G.O., D'Áuria S.R.N., Cristaldo G. \& Rocha H.C. 2001. Occurrence of canine visceral leishmaniasis in an agricultural settlement in the State of Mato Grosso do Sul, Brazil. Revta Soc. Bras. Med. Trop. 34(3):299-300.

Oliveira T.M.F.S., Furuta P.I., Carvalho D. \& Machado R.Z. 2008. A study of cross-reactivity in serum samples from dogs positive for Leishmania sp., Babesia canis and Ehrlichia canis in Enzyme-Linked Immunosorbent Assay and Indirect Fluorescent Antibody Test. Rev. Bras. Parasitol. Vet. 17(1):7-11.

Ozbel Y., Oskam L., Ozensoy S., Turgay N., Alkan M.Z., Jaffe C.L. \& Ozcel M.A. 2000. A survey on canine leishmaniasis in western Turkey by parasite, DNA and antibody detection assays. Acta Trop. 74:1-6.

Reis A.B. 2001. Avaliação de parâmetros laboratoriais e imunológicos de cães naturalmente infectados com Leishmania (Leishmania) chagasi, portadores de diferentes formas clínicas de infecção. Tese de Doutorado em Imunoparasitologia, Universidade Federal de Minas Gerais, Belo Horizonte. 176p.

Santa-Rosa A.C.I. \& Oliveira S.C.I. 1997. Leishmaniose visceral: breve revisão sobre uma zoonose reemergente. Clin. Vet. 2(11):24-28.

Silva E.S., Gontijo C.M.F., Pacheco R.S., Fiúza V.O.P. \& Brazil R.P. 2001. Visceral leishmaniasis in the metropolitan region of Belo Horizonte, State of Minas Gerais, Brazil. Mem. Inst. Oswaldo Cruz 96(3):285-291.

Slappendel R.J. \& Greene C.E. 1990. Clinical microbiology and infectious diseases of the dog and cat, p.450-458.In: Greene C.E. (Ed.), Leishmaniasis. W.B. Saunders, Philadelphia.

WHO 1999. Leishmaniasis control. Communicable Disease Surveillance and Response (CSR). World Health Organization <http://www.who.int/ emc/diseases/leish/leisgeo1.html> (Acessado em 15.08.2007). 